\title{
EATURES OF CHANGES IN INDIVIDUAL STATES OF THE NERVOUS SYSTEM OF STUDENTS OF SPECIAL MEDICAL GROUPS IN THE PROCESS OF PHYSICAL EDUCATION
}

\author{
E. Bezgrebelnaya, V. Koryahin, O. Blavt \\ Lviv Polytechnic National University, Ukraine
}

corresponding author-O. Blavt: oksanablavt@ukr.net

doi: $10.32626 / 2227-6246.2019-13.5-10$

The optimal organization of physical education classes to ensure a high level of somatic health of student youth is relevant for solving the problems of their psychophysical readiness to perform their professional duties. The purpose of the study: to identify the impact of physical education classes in accordance with an individually oriented program for students of special medical groups with diseases in the state of the nervous system to the state of this system. Material and methods. The participants of the experiment were 80 students of the Lviv Polytechnic National University during a three-year physical education course. To determine the effectiveness of a proven program of physical education special medical group for students with diseases in the state of the nervous system, cardiovascular tests have been used. Results. In terms of the general objectives of the study, the experiment can be considered quite effective. After the course of studies, we observe stabilization with a tendency to regress vegetative disorders, improvement of peripheral hemodynamics, against the background of reduction of clinical manifestations of diseases of the nervous system. The final statistical analysis of the obtained control results testifies to the positive dynamics of all the experimental parameters of the experimental group students, the dynamics leveling within $21 \%$. The quality of the studied parameters of the control group students during the physical education course is characterized by a significantly lower positive trend. Conclusions. The results of the three-year implementation of the physical education of special medical groups of the physical education program for students with diseases in the state of the nervous system showed a significantly higher $(p<0.05)$ effectiveness of the content in the influence on the functional state of the nervous system, compared with the current one. This is reflected in the significant improvement of the studied parameters with experimental groups students compared to control groups students.

Key words: student, special medical group, physical education, diseases of the nervous system.

\section{Introduction}

The health of the nation is determined primarily by the health of young people, which is an integral indicator of the social status of society and on which its future development depends [4].

In the National Doctrine of the Development of Education of Ukraine in the 21st Century, care for the health of young people, the development of a culture of healthy lifestyles in it is defined as one of the priority directions [9]. Thus, Ukraine actively perceived world trends in improving the health of the population through education. The
Безгребельна Є., Корягін В., Блавт О. Особливості зміни в індивідуальних станах нервової системи студентів спеціальних медичних груп в процесі фізичного виховання.

Анотація. Оптимальна організація занять фізичною культурою задля забезпечення високого рівня соматичного здоров'я студентської молоді $€$ актуальним для вирішення проблематики їхньої психофізичної готовності до виконання своїх професійних обов'язків. Мета дослідження: виявити вплив занять з фізичного виховання згідно індивідуально орієнтованої програми для студентів спеціальних медичних груп із захворюваннями в стані нервової системи на стан цієї системи. Матеріал і методи. В експерименті приймали участь 80 студентів із захворюваннями в стані нервової системи НУ «Львівська політехніка» протягом трирічного курсу фізичного виховання. Для визначення ефективності апробованої програми фізичного виховання для студентів із захворюваннями в стані нервової системи, використано кардіоваскулярні тести. Результати. Оцінювання результатів, з позицій загальних завдань дослідження, можна вважати експеримент доволі ефективним. Після проведеного курсу занять спостерігаємо стабілізацію з тенденцією до регресування вегетативних порушень, покращення периферичної гемодинаміки, на фоні зменшення клінічних проявів захворювань нервової системи. Підсумковий статистичний аналіз отриманих результатів контролю засвідчує позитивну динаміку усіх досліджуваних параметрів у студентів експериментальної групи, яка нівелює у межах до 30 \%. Висновки. Якісний стан дослідних параметрів у студентів контрольної групи у ході курсу занять характеризується значно меншою позитивною тенденцією. Результати трирічного упровадження у күрс фізичного виховання спеціальних медичних груп програми фізичного виховання для студентів із захворюваннями в стані нервової системи засвідчили значно вищу $(p<0,05)$ ефективність змісту у впливі на функціональний стан нервової системи, порівняно із чинною. Це відображено у достовірному покращанні досліджуваних параметрів у студентів експериментальних груп порівняно із контрольними.

Ключові слова: студент, спеціальна медична група, фізичне виховання, захворювання нервової системи.

problem of improving the educational function of education is complex and multifaceted. The problem is exacerbated by the fact that now only 6-10 percent of Ukrainian students have satisfactory health [1]. The importance and necessity of taking effective measures for the prevention of diseases among students is a major task of physical education in institutions of higher education [2]. In this context, the optimal organization of physical education in order to ensure a high level of somatic health of student youth is relevant for solving the problems of their psychophysical readiness to perform their professional duties [3; 4]. 
The urgency of the search for ways to increase the efficiency of physical education increases significantly in connection with the reorganization of the educational system of Ukraine in accordance with European standards. Taking into account the permanent increase in the number of students who are referred to the state of health in special medical groups for physical education $[1 ; 11]$, the search for ways to eliminate such a negative trend is of particular importance. Intelligence in this direction, along with the theoretical and practical significance for improving physical education in the special medical groups, also have social significance, as it is in the students' years that the foundation of the health of future professional specialists is laid. The latter brings it into the rank of the problem of paramount importance and activates the search for the most effective approaches in the outlined direction. Quite a large number of studies are devoted to the search for the effectiveness of physical education of students at special medical groups $[1 ; 2$; $4 ; 8 ; 11]$. At the same time, in scientific research the necessity of individualization of physical education with the account of violations in the state of health of special medical groups' students has been proved [7; 8; 11]. It is believed that the effectiveness of this process depends on the use of scientifically grounded individualized methodology [2; 3].

At the same time, in the domestic scientific literature, there are practically no references to the study of physical education in the special medical groups with a targeted orientation. In particular, the problems of physical education of students with diseases in the state of the nervous system are practically not considered in the existing scientific research. There is currently no consensus on the content of the physical education of students with diseases in the state of the nervous system. Constructive research in this direction was not carried out. At the same time, there is a perception of the need for such research, as diseases of the nervous system can progress throughout the life and affect the activities of other systems of the body and in general, on the quality of life of students [1; 4]. In addition, there is evidence of the dependence of physical capacity on the state of the nervous system [8; 11]. So, we join in the idea that the effectiveness of physical education of students to a large extent due to its correction based on the characteristics of diseases in the state of the nervous system of students.

The purpose of the work to identify the effects of physical education classes in an individualized program for special medical groups a students with diseases in the state of the nervous system on the state of the system.

\section{Material \& methods}

Participants. The experiment was attended by 80 students of Lviv Polytechnic National University with diseases of the nervous system during a three-year PE course, with equal numbers of female and male students participating. The research was conducted in compliance with the WMA Declaration of Helsinki, - Ethical Principles for Medical Research Involving Human Subjects, 2013. The study protocol was approved by the Ethical Committee of Lviv Polytechnic National University. For the duration of the research, according to the results of the medical examination, the selected students were directed to the special medical group. Four groups (two groups of males and two groups of females), being control groups (CG) and experimental groups (EG), were formed on the principle of cluster analysis for the distribution of the sample into homogeneous groups. The experimental group was formed of the students having a common feature (nosological characteristic) with satisfaction of the requirements regarding the adequacy of the sample size at the probability level $p<0.05$.

Procedures. For empirical research, a program of physical education adapted for students with diseases in the state of the nervous system was used. The decisive difference of such a program from the current is the ratio of physical education methods, which were obtained taking into account the recommendations on the effect of physical activity on the body in the presence of violations in the state of the nervous system. The program has been tested during an academic course of physical education in university. The research was conducted annually in the defined curriculum terms, following the same order of organization. To determine the effectiveness of the program of physical education for special medical groups students with diseases in the state of the nervous system, cardiovascular tests have been used. Solving the tasks of the study required the use of a research method that would allow relatively small changes in vegetative activity to be recorded using a simple, fast-acting test without any effect on the very activity of the student's body. Using simple objective non-invasive, reliable and accurate diagnostic methods - cardiovascular tests, it was possible to estimate the degree of violation of the pathological process on the autonomic nervous system. Specialists recommend that they be used to assess the process of urgent adaptation of the cardiovascular system to different types of load and to determine the functional state of the nervous system of persons with a wide range of diseases in this system. Interpretation of indicators of cardiovascular tests is based on representations about regulatory influences on the autonomic nervous system, and higher levels of management of physiological functions. 
The research uses the following indicators:

1. Determination of the difference between the maximum and minimum values of cardiointerval $R R$ during continuous recording of heart rate for EG during deep slow breathing (6 for $1 \mathrm{~min}$ ) and deduction of RR $\left(\mathrm{K}_{R-R}=(\mathrm{R}-\mathrm{Rmax}) /(\mathrm{R}-\mathrm{Rmin})\right.$, that tachycardia in rest and reducing the spread of $R R$ intervals indicate a deterioration of the parasympathetic function of the autonomic nervous system $[15 ; 16]$.

2. Assessment of the change in heart rate during ascension with the calculation of the ratio of $R-R$ intervals at the 30th and 15th blows from the onset of ascent $\left(K_{30: 15}\right)[5]$.

3. Valsalvi test: the student breathes into the mouthpiece, connected to the pressure gauge, and maintains pressure in the spirometer at $40 \mathrm{~mm} \mathrm{Hg}$. Art. within 10-15 seconds. Register the ECG before, during and after the test. Calculate the Valsalvi coefficient $\left(K_{\text {valsalvi }}\right)$ : the ratio of the extended $R-R$ interval in the first $20 \mathrm{~s}$ after the test to the shortened R-R interval during the sampling [5].

4. Orthostatic test, minus the difference for systolic blood pressure (SAP) in the position of lying and at the 3rd minute in standing position (DAP) [13].

5. Isometric test: Student compresses the dynamometer for 30 minutes from the maximum for 3 minutes.
Determine the change in diastolic blood pressure (DDAP) to the test and at the 3rd minute compression of the dynamometer [5]. This test characterizes the ability of the peripheral vessels to reduce, that is, the sympathetic function $[16 ; 18]$. Thus, the first three tests are aimed at the study of parasympathetic vegetative paths, the next two - on the study of sympathetic paths [5].

Statistical analysis. To characterize the results obtained, the indicators of descriptive statistics were used. The statistical significance of the results was determined using the methods of inductive statistics (Student's t-criterion). All statistical analyzes were performed using SPSS Version 21. Results of descriptive statistics in this study were presented as percentages. The 0.05, 0.01 and 0.001 levels of probability were used to indicate statistical significance [17].

\section{Results}

In order to ensure the validity of the results of experimental studies, a statistical analysis was performed at the beginning of the qualitative characteristics of the studied parameters of cardiovascular tests. The results of the study of the indices of students of EG and CG in this period did not differ significantly, which statistically confirms ( $p>0.05)$ and indicates the homogeneity of the contingent of the student sample (Table 1 ).

Table 1

Results of cardiovascular tests of students of EG with diseases of the nervous system

\begin{tabular}{|c|c|c|c|c|c|c|c|c|c|c|c|c|}
\hline \multirow{3}{*}{\multicolumn{2}{|c|}{$\begin{array}{l}\text { Investigated } \\
\text { parameters }\end{array}$}} & \multicolumn{10}{|c|}{ Period of the experiment } & \multirow{3}{*}{$\begin{array}{c}\text { Reliability of } \\
\text { discrepancies }(p)\end{array}$} \\
\hline & & \multicolumn{6}{|c|}{ at the beginning } & \multicolumn{4}{|c|}{ after } & \\
\hline & & $\bar{x}$ & $S$ & As & $M e$ & V & $\bar{x}$ & $S$ & As & Me & $\%$ & \\
\hline \multirow{2}{*}{$\begin{array}{l}\text { Heart rate } \\
\text { beats/min }\end{array}$} & $B$ & 12.18 & 1.99 & 0.36 & 6.11 & 16.8 & 14.18 & 1.87 & 0.32 & 0.34 & 16.41 & $<0,05$ \\
\hline & $G$ & 13.75 & 1.73 & 0.58 & 6.44 & 17.5 & 15.71 & 1.71 & 0.52 & 6.09 & 14.26 & $<0,05$ \\
\hline \multirow{2}{*}{$\mathrm{K}_{R-R}$} & $B$ & 1.167 & 0.028 & 0.7 & 2.13 & 17.4 & 1.236 & 0.052 & 0.68 & 4.98 & 13.52 & $<0,05$ \\
\hline & $G$ & 1.041 & 0.016 & 0.46 & 2.13 & 16.2 & 1.187 & 0.034 & 0.54 & 5.88 & 14.02 & $<0,05$ \\
\hline \multirow{2}{*}{$K_{30: 15}$} & $B$ & 1.015 & 0.006 & 0.53 & 0.43 & 14.7 & 1.192 & 0.026 & 0.3 & 6.43 & 17.43 & $<0,05$ \\
\hline & $G$ & 1.012 & 0.003 & 0.54 & 0.32 & 14.5 & 1.177 & 0.012 & 0.47 & 69.3 & 16.3 & $<0,05$ \\
\hline \multirow{2}{*}{$\mathrm{K}_{\text {Valsalvi }}$} & $B$ & 1.211 & 0.009 & 0.34 & 6.0 & 19.0 & 1.413 & 0.033 & 0.6 & 73.2 & 16.68 & $<0,05$ \\
\hline & $G$ & 1.193 & 0.009 & 0.22 & 4.78 & 10.4 & 1.388 & 0.021 & 0.45 & 1300 & 16.34 & $<0,05$ \\
\hline \multirow{2}{*}{$\begin{array}{c}\text { SAP, } \\
\mathrm{Mm} \mathrm{Hg}\end{array}$} & $B$ & 12.24 & 1.075 & 0.62 & 5.66 & 16.2 & 9.96 & 1.013 & 0.56 & 1401 & 18.46 & $<0,01$ \\
\hline & $G$ & 13.06 & 1.302 & 0.52 & 6.65 & 14.7 & 10.04 & 1.882 & 0.35 & 38.32 & 15.48 & $<0,05$ \\
\hline \multirow{2}{*}{$\begin{array}{c}\text { DAP, } \\
M m ~ H g\end{array}$} & $B$ & 13.54 & 0.885 & 0.2 & 69.9 & 14.5 & 10.66 & 0.717 & 0.52 & 40.92 & 21.27 & $<0,01$ \\
\hline & $G$ & 13.95 & 0.66 & 0.79 & 73.1 & 17.5 & 11.04 & 0.539 & 0.38 & 42.43 & 20.08 & $<0,01$ \\
\hline
\end{tabular}

$\mathrm{N} \circ \mathrm{t}$ e : here and after: $B$-boys, $G$ - girls; $\mathrm{K}_{30: 15}$ - heart rate change coefficient, $\mathrm{K}_{R-R}$ - respiratory test coefficient, $\mathrm{K}_{\mathrm{Valsalvi}}-\mathrm{Valsalvi}$ coefficient 
Thus, the studied sample is fully appropriate to the demands of representativeness, as it reproduces the characteristics of the general population.

The obtained results of cardiovascular tests before the beginning of the experiment generally showed a low functional reserve of the autonomic nervous system in the students of the studied sample and made it possible to determine the directions of possible correction for different types of deviations. In the majority of the studied students (75.6\%) of the experimental groups, violations in the functional state of the nervous system were revealed, which was manifested in the processes of disintegration between the nerve and humoral channels of regulation, mainly in the form of hyper sympathicotonic reactions. And since functional disorders of vegetative systems are not only risk factors for the formation of somatic pathology and a predictor of cardiovascular diseases, but also factors influencing the physical and mental development of students, such reactions are fully justified from the position of the terms of the beginning of education, when the physiological changes in the youth organisms coincide with social changes [18]. Considering that vegetative influence is one of the important factors of ensuring the proper level of adaptation processes and maintaining the internal homeostasis of the organism, especially in the presence of chronic diseases of the nervous system, vegetative regulation indicators were studied, which in general, the students of the EG and the CG did not have significant differences $(p<0.05)$.

Almost all of the examined students increased heart rate during cardiovascular examinations; these results were plausible $(p<0.05)$ in both groups of girls and in boys' groups. Despite the lower rates of heart rate in boys than girls, these differences are not reliable ( $p>0.05$ ) (Table 2).

Table 2

Results of cardiovascular tests of students of CG with diseases of the nervous system

\begin{tabular}{|c|c|c|c|c|c|c|c|c|c|c|c|c|}
\hline \multirow{3}{*}{\multicolumn{2}{|c|}{$\begin{array}{l}\text { Investigated } \\
\text { parameters }\end{array}$}} & \multicolumn{10}{|c|}{ Period of the experiment } & \multirow{4}{*}{$\begin{array}{c}\text { Reliability of } \\
\text { discrepancies } \\
(p)\end{array}$} \\
\hline & & \multicolumn{5}{|c|}{ at the beginning } & \multicolumn{5}{|c|}{ after } & \\
\hline & & $\bar{x}$ & $S$ & As & Me & $v$ & $\bar{x}$ & $S$ & As & Me & $\%$ & \\
\hline \multirow{2}{*}{$\begin{array}{l}\text { Heart rate } \\
\text { beats } / \text { min }\end{array}$} & $B$ & 13.02 & 2.072 & 0.47 & 69.3 & 15.1 & 13.11 & 2.094 & 0.23 & 6.0 & 0.69 & \\
\hline & G & 13.83 & 1.84 & 0.6 & 73.2 & 19.7 & 13.92 & 1.866 & 0.39 & 6.99 & 0.65 & $>0,05$ \\
\hline \multirow{2}{*}{$\mathrm{K}_{R-R}$} & $B$ & 1.155 & 0.038 & 0.45 & 1300 & 13.4 & 1.161 & 0.063 & 0.83 & 2.22 & 0.51 & $>0,05$ \\
\hline & G & 1.039 & 0.022 & 0.56 & 1401 & 19.1 & 1.042 & 0.045 & 0.37 & 2.11 & 0.28 & $>0,05$ \\
\hline \multirow{2}{*}{$K_{30: 15}$} & $B$ & 1.014 & 0.007 & 0.35 & 38.32 & 13.5 & 1.019 & 0.014 & 0.55 & 0.45 & 0.48 & $>0,05$ \\
\hline & G & 1.009 & 0.011 & 0.52 & 40.92 & 16.7 & 1.01 & 0.008 & 0.32 & 0.34 & 0.09 & $>0,05$ \\
\hline \multirow{2}{*}{$\mathrm{K}_{\text {Valsalvi }}$} & $B$ & 1.206 & 0.012 & 0.38 & 42.43 & 13.4 & 1.209 & 0.027 & 0.52 & 6.09 & 0.24 & $>0,05$ \\
\hline & $G$ & 1.190 & 0.015 & 0.67 & 40.11 & 10.1 & 1.198 & 0.025 & 0.68 & 4.98 & 0.67 & $>0,05$ \\
\hline \multirow{2}{*}{$\begin{array}{l}\text { SAP, } \\
\mathrm{Mm} \mathrm{Hg}\end{array}$} & $B$ & 12.15 & 1.005 & 0.51 & 36.32 & 15.4 & 12.18 & 1.011 & 0.54 & 5.88 & 0.24 & $>0,05$ \\
\hline & $G$ & 12.97 & 1.221 & 0.5 & 40.11 & 15.7 & 13.08 & 1.343 & 0.3 & 6.43 & 0.84 & $>0,05$ \\
\hline \multirow{2}{*}{$\begin{array}{c}\text { DAP, } \\
M m ~ H g\end{array}$} & $B$ & 13.45 & 0.675 & 0.54 & 42.04 & 12.2 & 13.56 & 0.556 & 0,47 & 69.3 & 0.66 & $>0,05$ \\
\hline & $G$ & 15.11 & 0.72 & 0.14 & 40.11 & 14.5 & 15.19 & 0.606 & 0.6 & 73.2 & 0.52 & $>0,05$ \\
\hline
\end{tabular}

The clarification of the nature of the reaction to stimulation of the parasympathetic department of the autonomic nervous system on the value of the Valsalvi coefficient, which is within the boundary-pathological values $(p<0.001)$, has shown the existence of disturbances in the functioning of the sympathetic and parasympathetic mechanisms of the baro-reflexes, which to some extent explains the violation of humoral vegetative regulation [5].Indicator $K_{30: 15}$ was in the zone of pathological values, indicating the presence of a state of vegetative dystonia, insufficiency of general influences and low reactivity of the parasympathetic NA. In general, these indices do not have sexual and intergroup differences ( $p>0.01)$. A nice feature on the test results at the limit of the limit values [19].

Consequently, according to the results of cardiovascular tests, no differences were detected between EG and CG for any of the parameters studied. The study of vegetative functions, namely the evaluation and analysis of the initial vegetative tone, vegetative reactivity and vegetative status, indicated an imbalance in the system of nervous 
regulation - the phenomenon of systemic vegetative degeneration [16]. And since the results of functional tests are determined by the state of the central nervous system and the vegetative-endocrine apparatus [5], respectively, the quantitative results of the integrative evaluation of cardiovascular reflexes had boundary-pathological significance in the student sample.

Manifestations of neurocirculatory vehato-vascular dysfunction in the form of frequent manifestations of headache were noted in $66.3 \%$ of students. In general, $70.1 \%$ of students had one or another form or two forms of violation of vegetative homeostasis at the same time. Considering the fact that it belongs to the determining place in the formation of health [15], then, obviously, this factor led to a decisive low level of somatic health for students with diseases of the nervous system.

After the course of studies, we observe stabilization with a tendency to regress vegetative disorders, improvement of peripheral hemodynamics, against the background of reduction of clinical manifestations of diseases of the nervous system.

\section{Discussion}

The practical significance of the results obtained is determined by the experimental implementation of the program of physical education targeted at students with diseases of the nervous system, which can increase the effectiveness of physical education. Taking into account the aforesaid at formation and realization of maintenance of physical activity of pupils with chronic diseases will provide increase of its efficiency in solving of both main and related tasks. That agrees with the available scientific literature data $[1 ; 2]$

The obtained results supplemented the data on the implementation of control procedures in the process of physical education of special medical groups' students $[2 ; 4 ; 11]$. At the same time, it broadens the information and confirms the conclusions about the possibility of obtaining new information on the progress of physical education and its effectiveness. According to the results of the investigation, the expediency of using the results of the control of the state of the nervous system for the correction of pedagogical influences in the process of physical education of the special medical group $[1 ; 8]$ has been proved.

For the first time, the research of the state of the nervous system in the special medical group according to the targeted correction of the means by the type of diseases is practically implemented, which makes it possible to take into account the individual-typological peculiarities of changes in the functional state of the nervous system of students under the influence of physical education. Therefore, the available dynamics of the studied parameters is considered as a criterion for the effectiveness of physical education in terms of deprivation of deviations in the state of health of students. Thus, the results of our study are confirmed by the data of scientists $[1 ; 3 ; 11]$, concerning changes in the state of the nervous system under the influence of physical education.

According to the results of the research, it was established that the main reason for introducing an individualized approach to the system of physical education of special medical group students in the university is the provision that this process should be guided by the individual characteristics of each student's health and the possibility of eliminating existing deviations by means of physical education, and, therefore, achievement of the highest results in such activity. The analysis of research and educational practice gives grounds for the conclusion that such an approach in the physical education of the special medical group, namely, taking into account the characteristics of the diseases of a certain contingent of students, determines the new prospects of physical education of students of the university in general. That finds its confirmation in a number of scientific works [1-4; 9].

The obtained results of cardiovascular tests of students of CG after the end of the study confirm the low level $[2 ; 8]$ of efficiency of the current physical education of special medical groups' students in solving the problem of forming the basics of physical potential of students during their stay in the university, and hence the need to find new ways, approaches to improving forms, tools, methods physical education in order to eliminate existing negative trends.

We join in the thought that the factor of this is the leveling of the specifics of the diseases. Thus, the empirical findings of the study confirm the evidence in the literature $[1 ; 11]$ that the effectiveness of physical education depends to a large extent on the implementation of addressable nosological correction of the above factors. The age of students of EG (17-20 years) is characterized by the further formation of the properties of the nervous system. This is manifested in the growth of the properties of the main nervous processes, sensorimotor reactions, which is confirmation of scientific data [6;7]. The obtained results of experimental research are quite natural, and taking into account the sexual aspects of individual ontogenesis [18], which are characterized by a certain intensity of development of functions of physiological systems, which determine the quantitative changes of certain parameters of the state of the nervous system. The results of the study indicate that the permanent control of the nervous system in the process of physical education of special medical group students with diseases of the nervous system provides the basis for an appropriate correction of the means of pedagogical influence for the effective solution of the objectives of the course. 


\section{Conclusions}

1. The issues of implementing diverse approaches in the direction of individualized correction of the process of physical education of special medical groups students are thoroughly investigated nowadays.

2. A problems of implementing an individualized approach to the physical education of students with diseases in the state of the nervous system at the proper level not explored.

\section{References}

1. Adyrkhaiev SG. (2014). Psychophysical condition of visually impaired students during physical education classes. European Scientific Journal, 10(3): 62-69.

2. Anikieiev DM. (2015). Criteria of effectiveness of students' physical education system in higher educational establishments. Physical education of students, 5: 3-8. doi: 10.15561/ 20755279.2015.0501.

3. Ayers SF. (2004). High School Students' Physical Education Conceptual Knowledge. Research Quarterly for Exercise and Sport, 75(3):272-287. doi: 10.1080/02701367.2004. 10609160.

4. Blavt O. (2016). System of control in physical education of students of special medical groups. Lviv: Polytechnic Publishing House.

5. Ewing DJ., \& Clarke BF. (1982). Brit. med. J., 285: 916-918.

6. Flec SJ. (2003). Cardiovascular adaptation to resistance training. Med. Sci. Sports Exerc, 5(20): 151

7. ledynak G., Galamandjuk L., Kyselytsia O., Balatska L., Nakonechnyi I., Mazur V. (2017). Physiological characteristics of pubertal schoolchildren with chronic diseases. Journal of Physical Education and Sport. 17(4): 2462-2466. doi:10.7752/jpes.2017.04275

8. Koryahin V., Blavt O., Bakhmat N., Guska M., Ludovyk T., Prozar M., Bodnar A., Kravets S., \& Bezgrebelnaya E. (2018). Differentiated correction of attention abilities of students with chronic diseases during physical education. Journal of Physical Education and Sport, 18(4): 2278-2283. doi: 10.7752/jpes.2018.04343.

9. Koryahin V., Blavt O., \& Grebinca G. (2016). Optimization of the technical training system. Journal of Physical Education and Sport, 16(2), 163: 1029-1030.
3. The scientifically based introduction of individualized physical education in the special medical groups, taking into account the specifics of the existing diseases, allows us to achieve positive results in terms of improving the health of students while studying in the university.

Conflict of interest. The authors state that there is no conflict of interest.

10. Koryahin V., \& Blavt O. (2013). Test control in physical education. LAP LAMBERT Academic Publishing is a trademark of: OmniScriptum $\mathrm{GmbH} \&$ Co. KG.

11. Koryahin V., \& Blavt O. (2013). Physical education of students in special medical groups. Lviv Polytechnic Publishing House.

12. Yedynak, G., Prusik K. (2013). Physical rehabilitation of children with orthopedic foot deformities in children with amendments the musculo-skeletal system. Journal Of Health Sciences, 3(8): 27-36.

13. MacDougall JD., \& Wenger HA. (1991). The purpose of physiological testing. Physiological Testing of High-Performance Athlete. Human kinetics, 4: 1-5.

14. Mancia G., \& Parati G. (2000). Ambulatory Blood Pressure Monitoring and Organ Damage. Hypertension, 36: 894-898.

15. Reiman MP., \& Manske R.C. (2009). Functional testing in human performance. Champaign IL : Human Kinetics, 308.

16. Shiyan, B. M, ledynak, G. A., Petryshyn, Y. V. (2012), Naukovi doslidzhennya u fizychnomu vykhovanni ta sporti [Scientific research in physical education and sports], Oiyum, Kamyanets-Podilsky, Ukraine.

17. Vincent WJ. (2005). Statistic in kinesiology, 3rd ed. Champaign IL: Human Kinetic.

18. Wilmore JH., \& Costill DL. (1994). Psychology sport and exercise. Champaign IL : Human Kinetics.

19. White W. (2001). Blood pressure monitoring in cardiovascular medicine and therapeutics. New Jersey: Humana Press.

Надійшла 30.05.2019 